\title{
FAKTOR LINGKUNGAN YANG BERHUBUNGAN DENGAN DIARE PADA ANAK BALITA DI DESA HAJIMENA KECAMATAN NATAR KABUPATEN LAMPUNG SELATAN TAHUN 2019
}

\author{
Danuja Prabaswara ${ }^{1 *}$ \\ ${ }^{1}$ Puskesmas Pasar Ambon Kota Bandar Lampung, Indonesia
}

\section{Artikel Info :}

Received 18 Juli 2021

Accepted 10 Agustus 2021

Available online 31 Agustus 2021

\section{Editor: Prayudhy Yushananta}

Keyword :

Diarrhea, toddlers,

environment, waste

Kata kunci :

Diare, balita, lingkungan, limbah

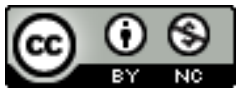

Ruwa Jurai: Jurnal

Kesehatan Lingkungan is licensed under a Creative Commons

Attribution-NonCommercial 4.0

International License.

\begin{abstract}
The diarrhea morbidity rate in the working area of the Hajimena Health Center tends to increase from year to year. During the last two years, the highest incidence of diarrheal disease was in the 1-4 year age group. This study aims to determine the relationship between environmental factors and the incidence of diarrhea in children under five. This study used a cross-sectional design. The research population was all children under five (1-5 years) in Hajimena Village, South Lampung Regency, 1,052 people. The sample in this study was 101 toddlers who were selected randomlycollecting data by observation and interviews. Data analysis was carried out univariate and bivariate using the Chi-Square test. The results of this study indicate a significant relationship between diarrhea in children under five with waste disposal facilities ( $p$-value $=0.010$ ) and waste water disposal facilities ( $p$-value $=0.001$ ). Meanwhile, clean water facilities and family latrine facilities, in this study, did not show a significant relationship. Increased knowledge and skills of the community in managing household waste is needed in an effort to reduce the incidence of diarrhea in children under five.
\end{abstract}

Angka kesakitan diare di wilayah kerja Puskesmas Hajimena cenderung meningkat dari tahun ke tahun. Selama dua tahun terakhir, kejadian penyakit diare tertinggi pada kelompok umur 1-4 tahun. Penelitian bertujuan mengetahui hubungan faktor keadaan lingkungan dengan kejadian diare pada anak balita. Penelitian ini menggunakan rancangan croos-sectional. Populasi penelitian adalah seluruh anak balita (1-5 tahun) di Desa Hajimena, Kabupaten Lampung Selatan, sebanyak 1.052 orang. Sampel pada penelitian ini sebanyak 101 balita yang dipilih secara random. Pengumpulan data dengan observasi dan wawancara. Analisis data yang dilakukan adalah secara univariat dan bivariat dengan menggunakan uji Chi Square. Hasil penelitian ini menunjukkan hubungan signifikan antara diare pada balita dengan sarana pembuangan sampah ( $p$-value $=0,010)$ dan sarana pembuangan air limbah $(p$-value $=0,001)$. Sedangkan sarana air bersih dan sarana jamban keluarga, pada penelitian ini tidak menunjukkan hubungan yang signifikan. Peningkatan pengetahuan dan keterampilan masyarakat dalam pengelolaan limbah rumah tangga sangat dibutuhkan dalam upaya menurunkan kejadian diare pada balita.

Corresponding author: : Danuja Prabaswara

Jl. Laks. Malahayati No. 11, Talang, Teluk Betung Selatan Kota Bandar Lampung, Lampung

Email: danujaprabaswara008@gmail.com

\section{PENDAHULUAN}

Penyakit diare masih menjadi salah satu penyebab utama kesakitan dan kematian pada anak balita. Secara global, 1 dari 9 kematian anak balita disebabkan oleh diare (Boyd et al., 2017). Di Indonesia, kejadian diare pada balita dan bayi sebesar $11,5 \%$ dan $9 \%$. Diare menjadi penyumbang dari 10,1\% kematian kelompok anak usia 12-59 bulan (Kementerian Kesehatan RI, 2020).

Kabupaten Lampung Selatan menjadi salah satu kabupaten yang berkontribusi terhadap kejadian diare di Provinsi Lampung. Pada tahun 2017, kejadian diare sebesar 268 kasus per 1.000 
penduduk, dan tahun 2018 meningkat mejadi 270 kasus per 1.000 penduduk (Dinas Kesehatan Kabupaten Lampung Selatan, 2017). Salah satu wilayah kerja puskesmas dengan kejadian diare tinggi adalah Puskesmas Hajimena. Selain selalu masuk dalam sepuluh besar penyakit (20132017), pada dua tahun terakhir, kejadian penyakit diare tertinggi terjadi pada kelompok umur 1-4 tahun (Puskesmas Hajimena, 2018). Kasus diare tertinggi dari tiga desa yang masuk dalam wilayah kerja Puskesmas Hajimena terdapat pada Desa Hajimena yaitu sebanyak 510 kasus, sementara Desa Sidosari sebanyak 257 kasus, dan Desa Pemanggilan sebanyak 253 kasus. Data lain menyebutkan bahwa cakupan air bersih di Desa Hajimena sebesar 66,03\%, dan jamban sehat sebesar $44,5 \%$ (Puskesmas Hajimena, 2018).

Penularan diare terjadi dari orang ke orang melalui beberapa media lingkungan, yaitu air, tangan, alat makan, tanah, dan lalat (Pickering et al., 2018; Yushananta \& Bakri, 2021). Sumber air yang telah terkontaminasi, infeksi bakteri, malnutrisi, kebersihan pribadi yang buruk dan rendahnya status sosial ekonomi berkontribusi terhadap diare pada anak balita (Imada, de Araújo, Muniz, \& de Pádua, 2016; Mar'atusholikhah, 2019; Pickering et al., 2018; Sanyaolu, Okorie, Marinkovic, Jaferi, \& Prakash, 2020; Ugboko, Nwinyi, Oranusi, \& Oyewale, 2020; UNICEF, 2020; Yushananta \& Bakri, 2021; Yushananta \& Usman, 2018).

Penyakit diare juga berkaitan dengan pengetahuan, pendidikan, dan pembuangan air kotor (Adisasmito, 2007; Pickering et al., 2018). Penelitian lain menyebutkan bahwa beberapa faktor yang menyebabkan tingginya kasus diare pada balita adalah sarana sanitasi, yaitu penyediaan air bersih, jamban, pembuangan sampah, dan saluran pembuangan air limbah (Kirana, 2016; Putra et al., 2015; Rohmah, 2019; Setiyono, 2019; Sukma et al., 2018; Syam \& Asriani, 2019). Penelitian bertujuan mengetahui hubungan faktor lingkungan dengan kejadian diare pada balita di Desa Hajimena.

\section{METODE}

Penelitian menggunakan rancangan crosssectional (potong lintang) yang dilaksanakan di Desa Hajimena Kecamatan Natar Kabupaten
Lampung Selatan, pada bulan Februari-Mei 2019. Populasi dalam penelitian ini adalah seluruh anak balita (usia 1-5 tahun), sebanyak 1.052 balita. Sampel sebanyak 101 anak balita, dihitung menggunakan rumus Slovin. Teknik pengambilan sampel yang peneliti gunakan dalam penelitian ini adalah dengan menggunakan sistematic random sampling. Responden pada penelitian ini adalah ibu dari balita.

Data dikumpulkan dengan cara wawancara kepada ibu balita, dan observasi terhadap kondisi sarana air bersih, kondisi jamban, kondisi pembuangan sampah dan pembuangan air limbah. Penilaian terhadap sarana air bersih meliputi jarak sumber air bersih dengan sumber pencemar, untuk air yang bersumber dari sumur penilaian dilakukan terhadap konstruksi sumur gali yaitu dinding sumur, bibir sumur, lantai, timba dan penutup. Sedangkan untuk air yang bersumber sumur bor penilaian dilakukan terhadap kedalaman pipa dari permukaan tanah, penggunaan pipa, selubung bor atau casing dan lantai di sekitar sumur bor.

Penilaian kondisi jamban meliputi jenis jamban, jarak septic tank dengan sumber air bersih, kemudahan dalam penggunaan dan membersihkan, ketersediaan air dan sabun cuci tangan serta kondisi lantai. Pembuangan sampah dinilai berdasarkan konstruksi tempat sampah, dan bebas serangga dan tikus. Sedangkan untuk saluran pembuangan air limbah penilaian dilakukan terhadap kepemilikan saluran pembuangan air limbah (SPAL), SPAL berfungsi dengan baik, tidak ada bau yang ditimbulkan, dan bebas serangga dan tikus.

Semua sarana dikelompokkan menjadi memenuhi syarat dan tidak memenuhi syarat berdasarkan (Kementerian Kesehatan RI, 2014b), dengan cara memberi score pada setiap item pengamatan yang memenuhi syarat. Apabila jumlah score $\geq 70 \%$ maka dinyatakan memenuhi syarat, sebaiknya jika < 70\% maka dinyatakan tidak memenuhi syarat. Data diolah dengan bantuan program komputer, dianalisis secara univariat menggunakan tabel distribusi frekuensi dan secara bivariat menggunakan chi square. Hasil analisis disajikan dalam bentuk tabel. 


\section{HASIL}

Puskesmas Hajimena memiliki luas wilayah kerja sekitar $11.650 \mathrm{~km}^{2}$, dengan jumlah kepala keluarga sebanyak 8.001. Hasil penelitian mendapatkan sebanyak $54,5 \%$ balita menderita diare dan $45,5 \%$ tidak menderita diare. Sebagian besar responden dengan pendidikan tamat SMP (53,5\%) dan sebagian lain tamat SMA (46,5\%). Pekerjaan responden paling banyak adalah tidak bekerja yaitu $61,4 \%$, buruh $28,6 \%$, wiraswasta 9,9\% dan petani $5,9 \%$.

Tabel 1. Diare pada balita dan karakteristik reponden

\begin{tabular}{lll}
\hline Variabel & $\mathrm{n}$ & $\%$ \\
\hline Diare & & \\
$\quad$ Diare & 55 & 55,4 \\
$\quad$ Tidak diare & 46 & 45,5 \\
Pendidikan & & \\
$\quad$ SMP & 54 & 53,5 \\
SMA & 47 & 46,5 \\
Pekerjaan & & \\
$\quad$ Tidak bekerja & 62 & 61,4 \\
$\quad$ Bekerja & 45 & 44,6 \\
\hline
\end{tabular}

Tabel 2 menunjukkan bahwa seluruh rumah tangga menggunakan air bersih dari sumur gali (100\%). Namun terdapat beberapa komponen yang belum memenuhi syarat, yaitu jarak $S A B$ dari sumber pencemar < 10 meter $(34,7 \%)$, dinding sumur disemen $<3$ meter $(24,8 \%)$, konstruksi bibir sumur yang tidak sempurna $(11,9 \%)$, tinggi bibir sumur $<70 \mathrm{~cm}(3,0 \%)$, lantai sumur yang tidak kedap air $(10,9)$, terdapat lantai bocor/retak $(10,9 \%)$ dan timba tidak di gantung dan diletakkan di lantai (11,9\%).

Seluruh rumah tangga (100\%) telah menggunakan jamban leher angsa (Tabel 2). Beberapa komponen yang belum memenuhi syarat adalah: jarak septic tank dari SAB $<10 \mathrm{~m}$ $(34,7 \%)$, terdapat serangga $(36,6 \%)$, jamban tidak mudah digunakan $(6,9 \%)$, jamban tidak mudah dibersihkan (6,9\%), tidak tersedia air yang cukup $(15,8 \%)$, tidak tersedia sabun cuci tangan $(16,8 \%)$ dan lantai tidak kedap air (4\%).

Hasil penilaian sarana pembuangan sampah (Tabel 2), diketahui bahwa sebanyak 58,4\% rumah tangga menggunakan tempat sampah berupa kantong plastik/karung/kardus. Kondisi tempat sampah sulit dibersihkan (58,4\%), terdapat serangga $(58,4 \%)$, konstruksi yang tidak kuat dan tidak kedap air $(58,4 \%)$.

Hasil penilaian terhadap SPAL (Tabel 2) mendapatkan sebanyak $51,5 \%$ responden tinggal di rumah yang tidak memiliki SPAL. Berdasarkan kondisinya, air limbah dialirkan secara terbuka $(77,5 \%)$, aliran air tidak lancar $(53,1 \%)$, menimbulkan bau $(51,0 \%)$ dan terdapat serangga $(51,0)$.

Tabel 2. Hasil Penilaian Faktor Lingkungan

\begin{tabular}{lllll}
\hline \multirow{2}{*}{ Komponen Penilaian } & Ya & \multicolumn{3}{l}{ Tidak } \\
\cline { 2 - 5 } & $\mathrm{n}$ & $\%$ & $\mathrm{n}$ & $\%$ \\
\hline Sarana Air Bersih & 101 & 100 & 0 & 0 \\
$\quad$ Jenis Sumur Gali & 66 & 65,3 & 35 & 34,7 \\
Jarak SAB dari Sumber Pencemar $\geq 10$ Meter & 76 & 75,2 & 25 & 24,8 \\
Dinding sumur di semen sedalam $\geq 3$ meter & 89 & 88,1 & 12 & 11,9 \\
Konstruksi bibir sumur (cicin) sempurna & 98 & 97 & 3 & 3 \\
Tinggi bibir sumur $\geq 70 \mathrm{~cm}$ & 90 & 89,1 & 11 & 10,9 \\
Lantai sumur kedap air & 89 & 88,1 & 12 & 11,9 \\
Timba digantung dan tidak diletakkan di lantai & & & & \\
Jamban keluarga & 101 & 100 & 0 & 0 \\
Jamban Leher Angsa & 66 & 65,3 & 35 & 34,7 \\
Jarak dengan SAB $\geq 10$ Meter & 64 & 63,4 & 37 & 36,6 \\
Bebas dari serangga (lalat, kecoak) dan tikus & 94 & 93,1 & 7 & 6,9 \\
Jamban mudah digunakan & 94 & 93,1 & 7 & 6,9 \\
Jamban mudah dibersihkan & 85 & 84,2 & 16 & 15,8 \\
Tersedia air yang cukup & 84 & 83,2 & 17 & 16,8 \\
Tersedia sabun cuci tangan & 97 & 96 & 4 & 4 \\
Lantai kedap air & & &
\end{tabular}




\begin{tabular}{lllll}
\hline \multirow{2}{*}{ Komponen Penilaian } & \multicolumn{3}{c}{ Ya } & \multicolumn{3}{c}{ Tidak } \\
\cline { 2 - 5 } & $\mathrm{n}$ & $\%$ & $\mathrm{n}$ & $\%$ \\
\hline Pembuangan Sampah & 42 & 41,6 & 59 & 58,4 \\
$\quad$ Terdapat tempat sampah/container & 42 & 41,6 & 59 & 58,4 \\
$\quad$ Tempat sampah mudah dibersihkan & 42 & 41,6 & 59 & 58,4 \\
$\quad$ Bebas dari serangga (lalat, kecoak) dan tikus & 42 & 41,6 & 59 & 58,4 \\
$\quad$ Konstruksi kuat dan kedap air & & & & \\
Saluran Pembuangan Air Limbah & 49 & 48,5 & 52 & 51,5 \\
$\quad$ Terdapat SPAL & 11 & 10,9 & 90 & 89,1 \\
$\quad$ SPAL tertutup & 23 & 22,8 & 78 & 77,2 \\
SPAL berfungsi dengan baik dan lancar & 24 & 23,8 & 77 & 76,2 \\
$\quad$ Tidak menimbulkan bau & 24 & 23,8 & 77 & 76,2 \\
$\quad$ Bebas dari serangga dan tikus & & &
\end{tabular}

Hasil penilaian sarana sanitasi selanjutnya dikelompokkan menjadi memenuhi syarat dan tidak memenuhi syarat, mengikuti Kementerian Kesehatan RI (2014). Sebagian besar sarana air bersih $(74,3 \%)$ dan jamban keluarga $(61,4 \%)$ telah memenuhi syarat kesehatan. Sebaliknya, sarana pembuangan sampah $(58,4 \%)$ dan SPAL $(80,2)$ lebih banyak yang tidak memenuhi syarat kesehatan (Tabel 3).

Tabel 3. Distribusi responden berdasarkan keadaan lingkungan

\begin{tabular}{lllll}
\hline \multirow{2}{*}{ Variabel } & MS & \multicolumn{3}{c}{ TMS } \\
\cline { 2 - 5 } & $\mathrm{n}$ & $\%$ & $\mathrm{n}$ & $\%$ \\
\hline Sarana air bersih & 75 & 74,3 & 26 & 25,7 \\
Sarana jamban keluarga & 62 & 61,4 & 39 & 38,6 \\
Sarana Pembuangan Sampah & 42 & 41,6 & 59 & 58,4 \\
Sarana Pembuangan Air Limbah & 20 & 19,8 & 81 & 80,2 \\
\hline
\end{tabular}

MS= Memenuhi syarat, TMS=Tidak Memenuhi Syarat

Analisis statistik dilakukan untuk menilai hubungan faktor lingkungan dengan kejadian diare pada balita (Tabel 4). Hasil penelitian mendapatkan bahwa lebih dari separuh balita yang mengalami diare tinggal di rumah tangga dengan sarana air bersih memenuhi syarat $(57,7 \%)$, dan tidak memenuhi syarat (53,3\%). Hasil analisis statistik tidak menunjukkan hubungan antara sarana air bersih dengan kejadian diare pada balita ( $p$-value $=0,876$ ).

Pada sarana jamban keluarga, proporsi balita mengalami diare lebih banyak tinggal di rumah dengan jamban yang memenuhi syarat $(58,1 \%)$, dibandingkan yang tidak memenuhi syarat (48,7\%). Hasil analisis statistik tidak menunjukkan hubungan antara jamban keluarga dengan kejadian diare pada balita ( $p$ value $=0,476$ ).
Sebagian besar balita dengan diare tinggal di rumah yang memiliki sarana pembuangan sampah yang tidak memenuhi syarat kesehatan (66,1\%). Sedangkan yang tinggal di rumah dengan sarana pembuangan sampah memenuhi syarat sebesar $38,1 \%$. Hasil analisis statistik menunjukkan hubungan antara sarana pembuangan sampah dengan kejadian diare pada balita $(p$-value $=0,0106)$.

Sebanyak $63,0 \%$ balita yang mengalami diare, tinggal di rumah dengan SPAL yang tidak memenuhi syarat kesehatan. Sedangkan yang mengalami diare dan tinggal di rumah dengan SPAL memenuhi syarat, hanya sebesar $20,0 \%$. Hasil analisis statistik menunjukkan hubungan antara SPAL dengan kejadian diare pada balita $(p$-value $=0,001)$. 
Tabel 4. Hubungan Kondisi lingkungan dengan kejadian diare

\begin{tabular}{|c|c|c|c|c|c|c|c|}
\hline \multirow{2}{*}{ Variabel } & \multicolumn{2}{|c|}{ Diare } & \multicolumn{2}{|c|}{ Tidak Diare } & \multirow{2}{*}{ N } & \multirow{2}{*}{$\%$} & \multirow{2}{*}{ P-value } \\
\hline & $\mathrm{n}$ & $\%$ & $\mathrm{n}$ & $\%$ & & & \\
\hline \multicolumn{8}{|l|}{ Sarana Air Bersih } \\
\hline Tidak Memenuhi syarat & 15 & 57,7 & 11 & 42,3 & 26 & 100 & \multirow{2}{*}{0.876} \\
\hline Memenuhi syarat & 40 & 53,3 & 35 & 46,7 & 75 & 100 & \\
\hline \multicolumn{8}{|l|}{ Sarana Jamban Keluarga } \\
\hline Tidak Memenuhi syarat & 19 & 48,7 & 20 & 51,3 & 39 & 100 & \multirow{2}{*}{0.476} \\
\hline Memenuhi syarat & 36 & 58,1 & 26 & 41,9 & 62 & 100 & \\
\hline \multicolumn{8}{|c|}{ Sarana Pembuangan Sampah } \\
\hline Tidak Memenuhi syarat & 39 & 66,1 & 20 & 33,9 & 59 & 100 & \multirow{2}{*}{0.010} \\
\hline Memenuhi syarat & 16 & 38,1 & 26 & 61,9 & 42 & 100 & \\
\hline \multicolumn{8}{|l|}{ SPAL } \\
\hline Tidak Memenuhi syarat & 51 & 63,0 & 30 & 37,0 & 81 & 100 & \multirow{2}{*}{0.001} \\
\hline Memenuhi syarat & 4 & 20,0 & 16 & 80,0 & 20 & 100 & \\
\hline
\end{tabular}

\section{PEMBAHASAN}

Hasil penelitian mendapatkan bahwa sarana air bersih tidak hubungan dengan kejadian diare pada anak balita di Desa Hajimena ( $p$-value= 0,876). Hasil ini sejalan dengan penelitian Selviana (2015), yang menyimpulkan tidak ada hubungan antara sarana air bersih dengan kejadian diare. Namun, berbeda dengan Putra et al. (2015) yang menyatakan adanya hubungan antara sarana air bersih dengan kejadian diare. Beberapa penelitian lain juga menyatakan hubungan yang erat antara saran air bersih dengan kejadian diare pada balita (Imada et al., 2016; Mar'atusholikhah, 2019; Pickering et al., 2018; Sanyaolu et al., 2020; Ugboko et al., 2020; UNICEF, 2020; Yushananta \& Bakri, 2021; Yushananta \& Usman, 2018). Sumber air minum merupakan sarana sanitasi penting yang berkaitan dengan kejadian diare, karena sebagian besar kuman infeksius penyebab diare ditularkan melalui jalur fecal oral (Kementerian Kesehatan RI, 2014a).

Berdasarkan hasil observasi, seluruh rumah tangga menggunakan sumur gali sebagai sumber air bersih. Kontruksi sumur gali sebagian besar sudah memenuhi syarat, namun ditemukan kontruksi sumur gali yang mengalami kerusakan pada bagian dinding, bibir, dan lantai sumur. Sehingga memungkinkan terjadinya pencemaran dan berisiko terhadap kejadian diare. Kualitas air bersih menjadi kunci dari risiko kejadian diare (Setiyono, 2019). Masyarakat juga harus mendidihkan air sebelum dikonsumsi untuk mematikan agen penyakit yang terdapat dalam air bersih (Kementerian Kesehatan RI, 2014a).

Hasil penelitian juga mendapatkan tidak terdapatnya hubungan antara jamban keluarga dengan kejadian diare pada anak balita ( $p$ value $=0,476$ ). Berbeda dengan hasil penelitian yang disampaikan Putra et al. (2015) dan Selviana (2015) yang menyatakan adanya hubungan antara kondisi sarana jamban keluarga dengan kejadian diare. Terdapatnya perbedaan disebabkan seluruh rumah tangga telah menggunakan jamban yang telah memenuhi syarat kesehatan (leher angsa dengan septic tank). Namun, perilaku dalam dalam pemeliharaan sarana masih kurang baik, serta tidak tersedia sabun untuk cuci tangan. Menurut Ahyanti et al. (2020), pemanfaatan jamban termasuk pemeliharaannya juga mendukung dalam mencegah terjadinya diare.

Jamban adalah suatu bangunan yang digunakan untuk membuang dan mengumpulkan kotoran manusia dalam suatu tempat tertentu, sehingga kotoran tersebut tidak menjadi penyebab penyakit dan mengotori lingkungan pemukiman (Rosita, Ahyanti, \& Yushananta, 2021; Yushananta, Ahyanti, \& Hasan, 2018). Syarat jamban yang baik antara lain berjarak minimal 10 meter dari sumber air minum, terdapat air bersih dan sabun, tidak terjangkau vektor seperti lalat, kecoak, tikus, mudah untuk digunakan, mudah dibersihkan, serta tidak menimbulkan bau (Kementerian Kesehatan RI, 2014a). 
Sarana pembuangan sampah menunjukkan hubungan yang bermakna dengan kejadian diare pada anak balita ( $p$-value $=0,010)$. Pengelolaan sampah yang tidak memenuhi syarat dapat berdampak pada gangguan kesehatan, salah satunya diare. Hasil observasi mendapatkan sebagian besar masyarakat masih menggunakan tempat sampah di dalam rumah dengan konstruksi yang tidak memenuhi syarat, yaitu memiliki tutup, kedap air, dan mudah dibersihkan. Sehingga menimbulkan bau, mengurangi nilai estetika, serta mengundang datangnya vektor dan tikus. Menurut Rahim, Pinontoan, \& Wilar (2016) dan Monica et al., (2020), sarana pembuangan sampah turut berkontribusi terhadap kejadian diare.

Sampah berkaitan erat dengan kesehatan masyarakat karena menjadi tempat hidup berbagai mikroorganisme penyebab penyakit, serta vektor dan tikus. Vektor seperti lalat dan kecoak akan datang karena tertarik dengan bau akibat pembusukan bahan organis pada sampah. Selanjutnya vektor dapat hinggap pada makanan sehingga mencemari makanan, dan menyebabkan diare jika dikonsumsi. Diperlukan pengelolaan sampah secara baik agar tidak menimbulkan berbagai gangguan penyakit (Purnama, 2016).

Pembuangan akhir sampah sebaiknya tidak dilakukan dengan cara dibakar. Pemusnahan sampah yang tidak baik, terutama sampah plastik, dapat menyebabkan gangguan kesehatan dan lingkungan (Setyowati \& Mulasari, 2013). Sebaiknya dilakukan pemisahan sampah organik dan anorganik. Selanjutnya sampah anorganik dapat digunakan (daur ulang), sedangkan sampah organik dapat dijadikan kompos. Perlu dilakukan upaya untuk meningkatkan pengetahuan dan keterampilan masyarakat dalam pengelolaan sampah rumah tangga.

Penelitian mendapatkan hubungan yang signifikan antara SPAL dengan kejadian diare pada anak balita ( $p$-value $=0,001$ ). Penelitian ini mempertegas hasil penelitian sebelumnya yang menyatakan bahwa sarana sanitasi merupakan hal penting yang harus diperhatikan karena dapat menjadi penyebab penularan diare (Rahim et al., 2016; Wibisono et al., 2020; Zicof \& Idriani, 2020).
Hasil observasi menunjukkan bahwa sebagian besar rumah memiliki SPAL dengan sistem terbuka, sehingga meyebabkan pencemaran sumber air, menimbulkan bau, dan menjadi tempat perindukan vektor. Menurut Kementerian Kesehatan RI (2014a), pengelolaan air limbah yang diterapkan harus memenuhi persyaratan, antara lain: 1) Tidak mengakibatkan kontaminasi terhadap sumber sumber air minum; 2) Tidak mengakibatkan pencemaran air permukaan; 3) Tidak menimbulkan pencemaran air untuk perikanan, air sungai, atau tempattempat rekreasi serta untuk keperluan seharihari; 4) Tidak dihinggapi oleh lalat, serangga dan tikus dan tidak menjadi tempat perkembangbiakan berbagai bibit penyakit dan vector; 5) Tidak terbuka dan harus tertutup jika tidak diolah; 6) Tidak menimbulkan bau atau aroma tidak sedap. Beberapa metode sederhana yang dapat digunakan untuk mengelola air limbah.

Air limbah harus dikelola agar tidak menimbulkan genangan, mencemari tanah dan sumber air, tidak menimbulkan bau, dan menjadi tempat perindukan vektor. Beberapa metode dapa dilakukan dalam pengelolaan limbah rumah tangga, yaitu membuat sumur atau lubang resapan (Hasanah, Buety, \& Iswadi, 2014; Ikhwan, 2013). Diperlukan penyuluhan untuk meningkatkan pengetahuan dan keterampilan masyarakat, khususnya rumah tangga dengan risiko penyakit berbasis lingkungan. Penyuluhan merupakan salah satu metode yang baik dalam menyampaikan informasi kepada masyarakat (Hariani \& Ramlah, 2019; Pudjaningrum, Wahyuningsih, \& Darundiati, 2016; Yuliasri \& Astuti, 2016).

\section{SIMPULAN}

Penelitian mendapatkan hubungan yang bermakna antara kejadian diare pada balita dengan sarana pembuangan sampah ( $p$ value $=0,010$ ) dan sarana pembuangan air limbah ( $p$-value=0,001). Sedangkan sarana air bersih dan sarana jamban keluarga, pada penelitian ini tidak menunjukkan hubungan yang signifikan. Diperlukan upaya untuk meningkatkan pengetahuan dan keterampilan masyarakat, khususnya dalam pengelolaan limbah rumah tangga, baik limbah padat maupun cair. Selain 
itu, upaya meningkatkan cakupan air bersih dan jamban sehat juga dibutuhkan dalam upaya mencegah penyakit diare serta penyakit berbasis lingkungan lainnya.

\section{DAFTAR PUSTAKA}

Adisasmito, W. (2007). Faktor Risiko Diare pada Bayi dan Balita di Indonesia. Jurnal Makara Kesehatan, 11(1), 1-10.

Ahyanti, M., Rosita, Y., \& Yushananta, P. (2020). Utilisation of the family latrine post declaration ODF. International Journal of Innovation, Creativity and Change, 13(2), 192-204.

Boyd, A. T., Cookson, S. T., Anderson, M., Bilukha, O. O., Brennan, M., Handzel, T., ... Gerber, M. (2017). Centers for Disease Control and Prevention Public Health Response to Humanitarian Emergencies, 2007-2016. Centers for Disease Control and Prevention, Emerging Infectious Diseases, 23(12).

Dinas Kesehatan Kabupaten Lampung Selatan. (2017). Profil Kesehatan Kabupaten Lampung Selatan. Kalianda: Dinas Kesehatan Kabupaten Lampung Selatan.

Hariani, \& Ramlah. (2019). Pelaksanaan Program Penanggulangan Diare di Puskesmas Matakali. Jurnal Kesehatan Masyarakat, 5(1), 34-46. https://doi.org/http://dx.doi.org/10.35329/jkes mas.v5i1.307

Hasanah, A. U., Buety, A., \& Iswadi. (2014). Desain Model Sumur Resapan Untuk Pengolahan Limbah Cair Rumah Tangga. Jurnal Fiska Dan Terapan, 1, 1-11.

https://doi.org/https://doi.org/10.24252/jft.v1i1. 15737

Ikhwan, Z. (2013). Faktor Individu Dan Keadaan Saluran Pembuangan Air Limbah (SPAL) Rumah Tangga Dengan Kejadian Diare Di Rt 01 Rw 09 Kelurahan. 4(2), 416-419. https://doi.org/http://dx.doi.org/10.26630/jk.v4i 2.86

Imada, K. S., de Araújo, T. S., Muniz, P. T., \& de Pádua, V. L. (2016). Socioeconomic, hygienic, and sanitation factors in reducing diarrhea in the Amazon. Revista de Saude Publica, 50, 1-10. https://doi.org/10.1590/S15188787.2016050006505

Kementerian Kesehatan RI. (2014a). Buku Pedoman Pengendalian Penyakit Diare. Jakarta: Ditjen Pengendalian Penyakit dan Penyesahatan Lingkungan.

Kementerian Kesehatan RI. Peraturan Menteri Kesehaan Republik Indonesia No. 3 Tahun 2014
Tentang Sanitasi Total berbasis Masyarakat. (2014).

Kementerian Kesehatan RI. (2020). Profil Kesehatan Indonesia Tahun 2019. In Short Textbook of Preventive and Social Medicine. https://doi.org/10.5005/jp/books/11257_5

Kirana, N. (2016). Hubungan antara faktor presdisposisi pada ibu terhadap kejadian diare pada balita. Jurnal Promkes, 6(1), 70-79.

Mar'atusholikhah, M. (2019). Perilaku Hidup Bersih dan Sehat sebagai Bentuk Pencegahan Diare Akut di PP Jamilurrahman Bantul. (2005). https://doi.org/10.31227/osf.io/xgcrp

Monica, D. Z., Ahyanti, M., \& Prianto, N. (2020). Hubungan Penerapan 5 Pilar Sanitasi Total Berbasis Masyarakat (STBM) Dan Kejadian Diare Di Desa Taman Baru Kecamatan Penengahan Kabupaten Lampung Selatan. Ruwa Jurai: Jurnal Kesehatan Lingkungan, 14(2), 71-77. https://doi.org/10.26630/rj.v14i2.2183

Pickering, A. J., Ercumen, A., Arnold, B. F., Kwong, L. H., Parvez, S. M., Alam, M., ... Luby, S. P. (2018). Fecal Indicator Bacteria along Multiple Environmental Transmission Pathways (Water, Hands, Food, Soil, Flies) and Subsequent Child Diarrhea in Rural Bangladesh [Research-article]. Environmental Science \& Technology, 52(14), 7928-7936.

https://doi.org/10.1021/acs.est.8b00928

Pudjaningrum, P., Wahyuningsih, N. E., \& Darundiati, Y. H. (2016). Pengaruh Metode Pemicuan Terhadap Perubahan Perilaku Masyarakat Buang Air Besar Sembarangan pada Masyarakat Kelurahan Kauman Kidul Kota Salatiga. Jurnal Kesehatan Masyarakatsyarakat, 4(5), 100-108.

Purnama, S. G. (2016). Modul pengolahan sampah organik rumah tangga. Denpasar: Departemen Kesehatan Lingkungan Prodi Kesehatan Masyarakat.

Puskesmas Hajimena. (2018). Profil Puskesmas Hajimena Tahun 2017. Hajimena, Lampung Selatan: Puskesmas Hajimena.

Putra, A. D. P., Rahardjo, M., \& Joko, T. (2015). Hubungan Sanitasi Dasar Dan Personal Hygiene Dengan Kejadian Diare Pada Balita Di Wilayah Kerja Puskesmas Tasikmadu Kabupaten Karanganyar. Universitas Diponegoro, Semarang.

Rahim, Z. H. A., Pinontoan, O. R., \& Wilar, R. (2016). Hubungan anatara Fasilitas Sanitasi Dasar dan Personal Hygiene dengan Kejadian Diare pada Balita di Wilayah Kerja Puskesmas banggai 
Kabupaten Banggai Laut. Universitas

Samratulangi, Manado.

Rohmah, S. (2019). Pengaruh Paparan, Lingkungan,

Tokoh Masyarakat, dan Tenaga Kesehatan terhadap Partisipasai dalam Desa Siaga. Jurnal

Kesehatan Bakti Tunas Husada: Jurnal Ilmu-Ilmu Keperawatan, Analis Kesehatan Dan Farmasi, 19(1), Hal. 133-149. https://doi.org/10.36465/jkbth.v19i1.460

Rosita, Y., Ahyanti, M., \& Yushananta, P. (2021). Model Pemberdayaan Masyarakat Menuju Desa ODF (1st ed.; M. B. Muvid, Ed.). Surabaya: CV. Global Aksara Pres.

Sanyaolu, A., Okorie, C., Marinkovic, A., Jaferi, U., \& Prakash, S. (2020). Global Epidemiology and Management of Acute Diarrhea in Children from Developing Countries. Ann Pediatr Child Health, 8(8), 1205.

Selviana, W. W. (2015). Terjadinya Penyakit Diare Akut pada Balita di Wilayah Pesisir. Universitas Muhammadiyah Pontianak.

Setiyono, A. (2019). Faktor Risiko Kejadian Diare pada Masyarakat Kota Tasikmalaya. Jurnal Kesehatan Komunitas Indonesia, 15(2), 49-59.

Setyowati, R., \& Mulasari, S. A. (2013). Pengetahuan dan Perilaku Ibu Rumah Tangga dalam Pengelolaan Sampah Plastik. Kesmas: National Public Health Journal, 7(12), 562. https://doi.org/10.21109/kesmas.v7i12.331

Sukma, H., Mursid, \& Nurjazuli. (2018). Hubungan Pengetahuan, Sikap Bab, Dan Kepemilikan Septic Tank Dengan Status Odf (Open Defecation Free) Di Kecamatan Candisari Kota Semarang. Jurnal Kesehatan Masyarakat (eJournal), 6(6), 143-149.

Syam, S., \& Asriani, A. (2019). Penerapan Sanitasi Total Berbasis Masyarakat (Stbm) Pilar 1 Stop Buang Air Besar Sembarangan (Stop Babs) Dengan Kejadian Penyakit Diare Di Kelurahan Lakkang Kecamatan Tallo Kota Makassar. Sulolipu: Media Komunikasi Sivitas Akademika Dan Masyarakat, 19(1), 109. https://doi.org/10.32382/sulolipu.v19i1.1035

Ugboko, H. U., Nwinyi, O. C., Oranusi, S. U., \& Oyewale, J. O. (2020). Childhood diarrhoeal diseases in developing countries. Heliyon, 6(4), e03690. https://doi.org/10.1016/j.heliyon.2020.e03690

UNICEF. (2020). Diarrhoea. Retrieved from UNICEF website: https://data.unicef.org/topic/childhealth/diarrhoeal-disease/

Wibisono, A. M., Marchianti, A. C. N., \& Dharmawan, D. K. (2020). Analisis Faktor Risiko Kejadian Diare Berulang Pada Balita Di Puskesmas Sumberjambe Kabupaten Jember. Journal of Agromedicine and Medical Sciences, 6(1), 43-52.

Yuliasri, T. R., \& Astuti, P. P. S. (2016). Pengaruh Penyuluhan Kesehatan terhadap Pengetahuan Ibu Tentang Penanganan Balita Diare Di Rumah. Jurnal Ilmu Kebidanan, 3(2), Hal. 145-152.

Yushananta, P., Ahyanti, M., \& Hasan, A. (2018). Community Based Total Sanitation in Muara Putih Village, Natar District, Pesawaran Regency. Sakai Sambayan: Journal of of Community Service, 2(2), 76. https://doi.org/10.23960/jss.v2i2.79

Yushananta, P., \& Bakri, S. (2021). Analisis Pembiayaan Peningkatan Akses Air Minum dan Sanitasi Sehat Dengan Pendekatan Cost Benefit Analysis (CBA). Jurnal Kesehatan, 12(2), 306. https://doi.org/10.26630/jk.v12i2.1855

Yushananta, P., \& Usman, S. (2018). The Incidence of Diarrhea in Babies Affected through the Cleanliness of Eating Utensils and Hands. Journal of Medical Science And Clinical Research, 6(9). https://doi.org/10.18535/jmscr/v6i9.137

Zicof, E., \& Idriani, E. (2020). Faktor Risiko Kejadian Diare Pada Balita Di Kota Padang. Jurnal Bidang Ilmu Kesehatan, 10(2), 169-182. https://doi.org/10.52643/jbik.v10i2.1097 